\title{
Rekonstruksi Hukum Pembangunan Dalam Kebijakan Pengaturan Lingkungan Hidup Dan Sumber Daya Alam
}

\author{
Oleh: Wahyu Nugroho' dan Agus Surono ${ }^{2}$
}

\begin{abstract}
Abstrak
Fungsi hukum dalam pembangunan nasional sebagai sarana pembaruan masyarakat secara singkat dikemukakan pokok-pokok pikiran sebagai berikut: pertama, bahwa hukum merupakan sarana pembaruan masyarakat didasarkan atas anggapan bahwa adanya keteraturan atau ketertiban dalam usaha pembangunan atau pembaruan itu merupakan sesuatu yang diinginkan atau bahkan dipandang (mutlak) perlu; kedua, bahwa hukum dalam arti kaidah atau peraturan hukum memang bisa berfungsi sebagai sarana pembangunan dalam arti penyalur arah kegiatan manusia ke arah yang dikehendaki oleh pembangunan atau pembaruan. Proses pembentukan perundang-undangan di bidang lingkungan hidup dan sumber daya alam, diperlukan grand design hukum sebagai sarana pembaharuan masyarakat, yang bertitik tolak kepada perubahan-perubahan sosial. Rekonstruksi hukum pembangunan dalam pembentukan hukum pasca reformasi, diarahkan pada daya dukung masyarakat, kesejahteraan sosial, dan lingkungan hidup. Selain

1 Mahasiswa Program Doktor Ilmu Hukum Universitas Padjadjaran \& Dosen Fakultas Hukum Universitas Sahid Jakarta Fakultas Hukum USAHID Jl. Prof. Dr. Soepomo, SH. No. 84 Tebet Jakarta Selatan 12870, Telepon +6221 8312813-15 Ext. 202, Faximile +62218354763 , Email: nugie_hukum@yahoo.co.id, wahyulaw86@yahoo.com.

2 Dosen Tetap Fakultas Hukum Universitas Al-Azhar Indonesia, Jl. Kompleks Masjid Agung Al Azhar, Jl. Sisingamangaraja, Kebayoran Baru, Selong, RT.2/RW.1, Selong, Kebayoran Baru, Kota Jakarta Selatan, Daerah Khusus Ibukota Jakarta 12110. Memperoleh gelar doktoral dari Fakultas Hukum Universitas Padjadjaran. Penulis dapat dihubungi melalui surono_uai@yahoo.com.
\end{abstract}


itu, proses pembentukan hukum harus menggunakan pendekatan yang holistik dan interdisipliner.

Kata kunci: hukum pembangunan, kebijakan, sumber daya alam, lingkungan hidup.

\begin{abstract}
The legal functions of national development as a means of social reform are briefly put forward as follows: first, that law is a means of social renewal based on the assumption that regularity or order in development or renewal is something desirable or even perceived (absolute) need; secondly, that law in the sense of rule or rule of law can indeed serve as a means of development in the sense of channeling the direction of human activity in the direction desired by development or renewal. The process of forming legislation in the field of environment and natural resources, required the grand design of law as a means of renewal of society, which dotted to social changes. Reconstruction of development law in the formation of post-reform law, directed to the support of society, social welfare, and environment. In addition, the legal establishment process should use a holistic and interdisciplinary approach.
\end{abstract}

Keywords: law of development, policy, natural resources, environmental.

\title{
1. Pendahuluan
}

Keterlibatan publik dalam setiap penentu kebijakan, keputusan hukum dan kekuasaan dapat memiliki daya laku yang efektif ketika sebuah peraturan atau kebijakan tersebut memiliki kemanfaatan bagi masyarakat. Hal ini seperti gagasan Eugen Ehrlich, seorang yuris berkebangsaan Austria penganut legal pluralism yang memperkenalkan konsep living law of the people (hukum yang hidup dari rakyat). Dalam konsepnya, Ehrlich berpendapat bahwa hukum yang hidup dan baik itu adalah berasal dari rakyat atau hukum yang relevan sesuai kehendak rakyat. ${ }^{3}$

3 Hedar Laudjeng dan Rikardo Simarmata, Pendekatan Madzhab Hukum Non-Positivistik dalam Bidang Hukum Sumber Daya Alam dalam Wacana, Edisi 6 Tahun II, (Jakarta: HuMa, 2000), hlm. 119. 
Konsep Ehrlich kemudian diikuti oleh Roscoe Pound melalui teori hukumnya law as a tool of social engineering atau hukum sebagai alat perekayasa sosial. ${ }^{4}$ Konsep-konsep dan kemudian menjadi teori hukum pembangunan oleh Mochtar Kusumaatmadja secara historis merupakan modifikasi dari konsep Roscoe Pound di Amerika dengan menyesuaikan kondisi Indonesia dan dimulai dari pembentukan hukum (law making), selain putusan pengadilan. Politik hukum perundang-undangan dan kebijaksanaan akan sangat menentukan arah suatu kebijakan apakah memiliki nilai kemanfaatan atau kontraproduktif. Rumusan kedua pemikir tersebut menunjukkan kompromi yang cermat antara hukum yang tertulis sebagai kebutuhan masyarakat hukum dengan the living law sebagai wujud penghargaan terhadap pentingnya peranan masyarakat dalam pembentukan hukum dan orientasi hukum. ${ }^{5}$

Teori hukum pembangunan yang digagas oleh Mochtar Kusumaatmadja mengenai fungsi hukum dalam pembangunan nasional yang digambarkan dengan ungkapan "sebagai sarana pembaruan masyarakat" atau sebagai sarana pembangunan" dapat secara singkat dikemukakan pokok-pokok pikiran sebagai berikut: pertama, bahwa hukum merupakan sarana pembaruan masyarakat didasarkan atas anggapan bahwa adanya keteraturan atau ketertiban dalam usaha pembangunan atau pembaruan itu merupakan sesuatu yang diinginkan atau bahkan dipandang (mutlak) perlu; kedua, bahwa hukum dalam arti kaidah atau peraturan hukum memang bisa berfungsi sebagai alat (pengatur) atau sarana pembangunan dalam arti penyalur arah kegiatan manusia ke arah yang dikehendaki oleh pembangunan atau pembaruan. Kedua fungsi tersebut diharapkan dapat

4 Roscoe Pound membahas secara rinci, teliti dan luas terhadap Sociological Jurisprudence di Amerika dengan lebih mengutamakan enam hal, yakni: (a) membahas dampak sosial yang nyata dari peran lembaga dan pemberlakuan doktrin-doktrin hukum; (b) mengajukan studi sosiologis berkenaan dengan studi hukum untuk menyiapkan perundang-undangan, karena hukum dianggap sebagai lembaga sosial yang dapat diperbaiki oleh usaha-usaha sosial bijaksana untuk menemukan cara-cara terbaik; (c) mengembangkan efektivitas studi tentang cara membuat peraturan yang lebih menekankan pada tujuan sosial untuk dicapai oleh/ secara hukum, dan bukan pada sanksi; (d) melakukan studi sejarah hukum sosiologis tentang dampak sosial yang ditimbulkan oleh doktrin hukum dan cara mengembangkannya; (e) membela pelaksanaan hukum yang adil, dengan mendesak agar ajaran-ajaran hukum harus dianggap sebagai petunjuk pada hasil yang adil bagi masyarakat; dan (f) mengusahakan efektifnya pencapaian tujuan hukum. Lihat: RB. Soemanto, Hukum dan Sosiologi Hukum, Lintasan Pemikiran, Teori dan Masalah, (Surakarta: Sebelas Maret University Press, 2006), hlm. 102.

5 Lili Rasjidi dan I.B. Wyasa Putra, Hukum Sebagai Suatu Sistem, (Bandung: Remaja Rosda Karya, 1993), hlm. 83. 
dilakukan oleh hukum di samping fungsinya yang tradisional, yakni untuk menjamin adanya kepastian dan ketertiban. ${ }^{6}$ Dalam konteks produk legislasi melalui proses pembentukan perundang-undangan di bidang lingkungan hidup dan sumber daya alam oleh Dewan Perwakilan Rakyat (DPR) dan pemerintah, diperlukan kerangka dasar hukum sebagai sarana pembaharuan masyarakat. Kerangka ini bertitik tolak kepada perubahan-perubahan sosial (social of change) atau rekayasa sosial (social engineering) disesuaikan dengan kebutuhan masyarakat kontemporer. Hal tersebut didesain sedemikian rupa dalam rangka mewujudkan keadilan sosial (social justice). Dinamika masyarakat yang selalu bergerak ke arah partisipasi dalam proses pembuatan kebiijakan dan perundang-undangan, seperti dengar pendapat umum, aspirasi daerah, dan lain sebagainya sebagai bahan masukan untuk diakomodasi ke dalam kebijakan sesuai dengan kehendak rakyat.

Amandemen UUD 1945 mengenai rumusan Pasal 337 merupakan rumusan yang mengatur secara prinsip mengenai perekonomian negara yang dibangun pada masa reformasi. Dalam kurun waktu lebih tiga dasawarsa terakhir, politik pembangunan hukum nasional diarahkan menganut ideologi sentralisme hukum (legal centralism). Hal ini secara sadar dimaksudkan untuk mendukung paradigma pembangunan yang semata-mata diorientasikan untuk mengejar pertumbuhan ekonomi (economic growth development paradigm). Implikasinya, sumber daya alam sebagai modal utama pembangunan bukan dikelola secara berkelanjutan, tetapi justru dieksploitasi untuk mengejar target-target pertumbuhan ekonomi. Karena itu, instrumen hukum yang digunakan untuk mendukung paradigma pembangunan ekonomi seperti dimaksud di atas cenderung bercorak sentralistik, sektoral, memihak kepada pemodal besar (capital oriented), eksploitatif, dan bernuansa

6 Mochtar Kusumaatmadja, Konsep-Konsep Hukum dalam Pembangunan, Cet. I, (Bandung: PT Alumni, 2002), hlm. 87-88.

7 Konstitusionalitas Norma dalam Pasal 33 UUD 1945 hasil empat kali amandemen terdiri dari 5 ayat dengan rumusan: (1) Perekonomian disusun sebagai usaha bersama berdasar atas asas kekeluargaan; (2) Cabang-cabang produksi yang penting bagi negara dan yang menguasai hajat hidup orang banyak dikuasai oleh negara; (3) Bumi, dan air, dan kekayaan alam yang terkandung didalamnya dikuasai oleh negara dan dipergunakan sebesar-besarnya kemakmuran rakyat; (4) Perekonomian nasional diselenggarakan berdasar atas demokrasi ekonomi dengan prinsip kebersamaan, efisiensi berkeadilan, berkelanjutan, berwawasan lingkungan, kemandirian, serta dengan menjaga keseimbangan kemajuan dan kesatuan ekonomi nasional; dan (5) Ketentuan lebih lanjut mengenai pelaksanaan Pasal ini diatur didalam undangundang. 
represif dengan menggunakan pendekatan keamanan (security approach). ${ }^{8}$

Pemikiran hukum pembangunan yang digagas oleh Mochtar Kusumaatmadja pada masa pemerintahan Orde Baru telah merasuk ke dalam Garis-Garis Besar Haluan Negara (GBHN) tahun 1972. Dalam GBHN, pembangunan hukum senantiasa mengorientasikan hukum sebagai sarana untuk melakukan pembaharuan masyarakat. Muatan substansial yang kental dengan teori hukum pembangunan tersebut ternyata sulit diterapkan di masa itu dengan penyebab utamanya pemerintahan yang bersifat otoriter, sekalipun karakter hukumnya responsif. Permasalahan lingkungan hidup (environmental problem) pada masa kejayaan teori hukum pembangunan yang berorientasi pada hukum sebagai sarana pembaharuan masyarakat sulit terpecahkan dengan baik. Penyebabnya, karena budaya hukum masyarakat yang belum terbangun, serta rendahnya tingkat ketaatan badan usaha dan masyarakat terhadap instrumen, peraturandan perizinan lingkungan. Dalam rangka mendorong ketaatan industri terhadap peraturan lingkungan hidup, Kementerian Lingkungan Hidup dan Kehutanan (KLHK) melaksanakan Program Penilaian Peringkat Kinerja Perusahaan (PROPER). PROPER bertujuan untuk mendorong industri menerapkan prinsip ekonomi hijau dengan kriteria penilaian kinerja sistem manajemen lingkungan, efisiensi energi, konservasi air, pengurangan emisi, perlindungan keanekaragaman hayati, 3R limbah B3 dan limbah padat non-B3 serta mengurangi kesenjangan

8 I Nyoman Nurjaya, Pengelolaan Sumber Daya Alam Dalam PerspektifOtonomi: Tinjauan Hukum dan Kebijakan, Jurnal Suloh, Vo. V, No. 1, (Lhokseumawe: Fakultas Hukum Unimal, April 2007), hlm. 1. 
ekonomi dengan menerapkan program pemberdayaan masyarakat. ${ }^{9}$

Dalam konteks penegakan hukum lingkungan, yang bertanggungjawab di level pusat adalah Direktorat Jenderal Penegakan Hukum Lingkungan Hidup dan Kehutanan (Gakum LHK), Kementerian Lingkungan Hidup dan Kehutanan (KLHK). Direktorat tersebut terbentuk sejak pada Juni 2015 dan telah bertugas efektif melaksanakan upaya-upaya penegakan hukum. Selain penanganan kasus, KLHK juga melakukan pencegahan tindakan pidana peredaran hasil hutan dan pengamanan kawasan hutan, yang dilaksanakan pada 187 lokasi di seluruh

9 Program Penilaian Peringkat Kinerja Perusahaan (PROPER) telah dimulai sejak tahun 1996 yang diikuti 96 perusahaan, dan saat itu tingkat ketaatan baru $46 \%$. Hal yang menggembirakan, pada tahun 2017 ini tingkat ketaatan perusahaan mencapai $92 \%$ atau meningkat $7 \%$ dari tahun lalu. PROPER telah mendapat apresiasi dari World Bank, PROPER juga dijadikan penilaian Key Performance Index (KPI) perusahaan. PROPER dijadikan sebagai prasyarat analisa perbankan, bahkan PROPER menjadi acuan pemberian penghargaan oleh kementerian lain. Pengalaman di tahun 2016, jumlah peserta PROPER mencapai 1.930 perusahaan yang terdiri dari 111 jenis industri, dengan tingkat ketaatan PROPER mencapai 85\%. Peraih peringkat EMAS sebanyak 12 perusahaan, HIJAU 172 perusahaan, BIRU 1.422 perusahaan, MERAH 284 perusahaan, HITAM 5 perusahaan, dan 35 perusahaan lainnya tidak diumumkan terdiri dari 13 perusahaan dalam proses penegakan hukum dan 22 perusahaan tutup/tidak beroperasi. Parameter capaian PROPER yang bisa dihitung selama 2 tahun terakhir (2016 - 2017) menunjukkan bahwa dana bergulir di masyarakat melalui program CSR mencapai Rp. 7 Triliun; Efisiensi energi 230 juta GJ; Penurunan emisi Gas Rumah Kaca 33 juta ton CO2 Equivalen; Efisiensi Air 492 juta m3; Penurunan emisi konvensional 135 juta ton; Penurunan beban air limbah 535 juta ton; Reduksi limbah padat non B3 11 juta ton; dan Reduksi limbah B3 13 juta ton. Peringkat PROPER dibagi menjadi 5 yaitu EMAS, HIJAU, BIRU, MERAH, dan HITAM. Peringkat tertinggi adalah EMAS dan peringkat terburuk adalah HITAM. Perusahaan yang memperoleh peringkat EMAS adalah perusahaan yang telah secara konsisten menunjukkan keunggulan lingkungan dalam proses produksi, melaksanakan bisnis yang beretika, dan bertanggung jawab terhadap masyarakat. Aspek penilaian ketaatan yang dievaluasi dalam penghargaan PROPER meliputi izin lingkungan, pengendalian pencemaran air, pengendalian pencemaran udara, pengolahan limbah B3, dan potensi kerusahan lahan khusus untuk kegiatan pertambangan. Lihat: http://ppid. menlhk.go.id/siaran_pers/browse/943, diakses pada tanggal 2 Februari 2018. 
Indonesia. $^{10}$

Rekonstruksi pemikiran hukum pembangunan sangat perlu dilakukan pasca reformasi yang dimulai sejak tahun 1999 hingga saat ini, khususnya perundangundangan di bidang lingkungan hidup dan sumber daya alam. Hal tersebut dikarenakan pemikiran dan peran masyarakat berkembang sangat dinamis dalam merespon kebijakan maupun penegakan hukum.

Dasar argumentasi tersebut sebagai latar belakang pemikiran juga diperkuat dalam literatur yang lain tentang teori-teori besar dalam hukum (grand theory), menyatakan bahwa di masa pemerintahan Presiden Soeharto, hukum sebagai sarana (alat) pembangunan (a tool of development) dimana sektor hukum sangat didayaupayakan untuk ikut menyukseskan pembangunan. Namun, sayangnya karena rendahnya kesadaran hukum dari para pembuat dan penegak hukum waktu itu, menyebabkan hukum sebagai sarana (alat) pembangunan berubah fungsi menjadi hukum sebagai alat untuk mengamankan pembangunan, yang

10 Menurut Rasio Ridho Sani, Direktur Jenderal Gakkum Lingkungan Hidup dan Kehutanan di Gedung Manggala Wanabakti, Jakarta, sebanyak 200 pengaduan kasus yang diterima oleh Kementerian Lingkungan Hidup dan Kehutanan (LHK) pada 2017, sampai Mei ini telah tertangani hampir 95\%. Sebanyak 75 persen terselesaikan dan sisanya dalam proses. Berdasarkan hasil kegiatan tersebut, selama tahun 2015-2017, tercatat pembalakan liar sebanyak $7.090 \mathrm{m3}$, perambahan kawasan seluas kurang lebih 4,2 juta Ha, dan peredaran tumbuhan dan satwa liar sebanyak 11.636 unit. “Dalam melakukan penegakan hukum, KLHK menggunakan tiga instrumen yaitu penerapan sanksi administrasi, penegakan hukum pidana, dan penegakan hukum perdata, termasuk untuk penanganan kasus pencemaran lingkungan, serta kebakaran hutan dan lahan". Sebanyak 393 sanksi administrasi diterbitkan selama dua tahun ini, terdiri dari 189 surat peringatan, 23 teguran tertulis, 156 paksaan pemerintah, 21 pembekuan izin, dan 3 pencabutan izin. Dalam penanganan kasus pidana, sebanyak 381 kasus telah masuk P-21, sedangkan untuk kasus perdata. Rasio Radho menerangkan telah dilakukan melalui kesepakatan di luar pengadilan sebanyak 40 kasus, serta melalui pengadilan dihasilkan beberapa putusan dan eksekusi. Kemajuan proses penegakan hukum terhadap beberapa kasus strategis, antara lain yaitu : 1. Bersama-sama Kementerian Koordinasi Bidang Kemaritiman, mendaftarkan gugatan terhadap tiga perusahaan asing asal Thailand ke Pengadilan Negeri Jakarta Pusat (23/5/2017), atas kasus ledakan tidak terkendali di Sumur Minyak H1 - ST1 yang terjadi 21 Agustus 2009, sekitar 51 mil laut sebelah tenggara Pulau Rote, Provinsi Nusa Tenggara Timur; 2. Perambahan lahan oleh kebun sawit seluas total 47.000 ha di kawasan hutan Padang Lawas, Sumatera Utara, dimana pemilik perusahaan dengan inisial DLS telah ditetapkan sebagai tersangka (17/5/2017); 3. Kasus kebakaran hutan dan lahan oleh PT. JJP, yang telah diputuskan oleh Pengadilan Tingggi DKI Jakarta, harus membayar ganti rugi Rp 119.888.500.000 dan memulihkan lahan 1.000 ha dengan biaya pemulihan Rp 371.137.000.000 (10/03/2017); 4. Pengenaan sanksi administrasi Tahun 2017 terhadap 53 perusahaan; dan 5. Penanganan kasus kandasnya kapal di perairan Bangka Belitung dan Taman Nasional Karimun Jawa. Lihat: http://www.mediaindonesia.com/news/read/106307/95-persen-kasus-penegakan-hukum-lhk-tertanganihingga-mei-2017/2017-05-26, diakses pada tanggal 02 Februari 2018. 
mempunyai konsekuensi munculnya banyak hukum yang sangat represif dan melanggar hak-hak masyarakat, mengantarkan banyak aktivis ke rumah penjara atau ke liang kubur. ${ }^{11}$

Pemikiran hukum pembangunan bertumpu pada aspek hukum sebagai sarana pembaharuan masyarakat, dalam hal ini permasalahan lingkungan di segala sektor di bidang sumber daya alam akan menjadi perubahan sosial bagi masyarakat sekitar. Diharapkan melalui pembentukan hukum, teori hukum pembangunan mampu diterapkan dengan baik oleh aparat pemerintahan dan aparat hukum dengan orientasi rekayasa sosial. Hukum pembangunan akan direkonstruksi dalam konteks pembentukan hukum di bidang lingkungan hidup dan sumber daya alam pasca reformasi sejak tahun 1999 hingga sekarang. Dengan demikian, berdasarkan ruang lingkup tersebut, permasalahan yang muncul dalam paper ini adalah:

1. Bagaimana diagnosa hukum pembangunan dalam kebijakan pembentukan perundang-undangan lingkungan hidup dan sumber daya alam sebelum dan sesudah reformasi?

2. Bagaimana rekonstruksi hukum pembangunan dalam kebijakan pengaturan lingkungan hidup dan sumber daya alam?

\section{Diagnosa Hukum Pembangunan Dalam Kebijakan Pembentukan Perundang-Undangan Lingkungan Hidup dan Sumber Daya Alam Sebelum dan Sesudah Reformasi}

Hukum merupakan bagian dari karya cipta manusia yang dimanfaatkan untuk menegakkan martabat manusia. Relevansinya dengan nilai dasar kebangsaan ialah mewujudkan konsepsi keadilan yang beradab, seperti sila kedua Pancasila. ${ }^{12}$ Oleh karena itu, hukum sebagai sarana pembangunan dan pembaharuan masyarakat hendaknya diwujudkan dalam pembentukan hukum (regulasi) di sektor-sektor strategis berkaitan dengan pengelolaan lingkungan hidup dan sumber daya alam.

11 Munir Fuady, Teori-Teori Besar Dalam Hukum (Grand Theory), Cet. 2, (Jakarta: Kencana Prenadamedia Group, 2013), hlm. 259.

12 Laksanto Utomo, "Penerapan Hukum Progresif dalam Penemuan Hukum oleh Hakim untuk Menciptakan Keadilan", dalam Refleksi dan Rekonstruksi Ilmu Hukum Indonesia, Cet. I, (Yogyakarta, Diterbitkan atas Kerjasama Thafa Media dan Asosiasi Sosiologi Hukum Indonesia Bagian Hukum dan Masyarakat Fakultas Hukum Undip, 2012), hlm. 284. 
Dalam kaitannya dengan fungsi kaidah hukum, Sudikno Mertokusumo mengatakan fungsi kaidah hukum pada hakekatnya adalah untuk melindungi kepentingan manusia. Kaidah hukum bertugas mengusahakan keseimbangan tatanan didalam masyarakat dan kepastian hukum agar tujuan hukum tercapai, yaitu ketertiban masyarakat. ${ }^{13}$ Agar kepentingan manusia terlindungi, maka hukum harus dilaksanakan. Pelaksanaan hukum dapat berlangsung secara normal, damai, tetapi dapat terjadi juga karena pelanggaran hukum. Dalam hal ini, hukum yang telah dilanggar itu harus ditegakkan. Melalui penegakan hukum inilah, hukum menjadi kenyataan. ${ }^{14}$ Sejumlah kaidah atau norma yang diatur dalam perundang-undangan lingkungan hidup dan sumber daya alam sudah semestinya melindungi perilaku manusia dari perbuatan eksploitasi sumber daya alam dan perusakan lingkungan, seperti pembakaran hutan, pencemaran sungai dan lautan.

Khudzaifah Dimyati dalam disertasinya mengklasifikasikan perkembangan teorisasi hukum dari hukum alam, hingga hukum modern masa transisi. Disini penulis lebih menyoroti teori hukum pembangunan yang berkembang pesat di era orde baru kemudian menjelma dalam bentuk GBHN (Garis-garis Besar Haluan Negara). Seiring dengan pesatnya teori hukum pembangunan pada waktu itu, berkembang pula isu-isu lingkungan hidup, pencemaran atau kerusakan lingkungan. ${ }^{15}$ Teori hukum yang berkembang orde baru dalam hal ini teori hukum pembangunan. Karakteristik tipologi pemikiran hukum pada periode era orde baru sangat dipengaruhi oleh suasana fenomena hukum yang melingkupinya. Kecenderungan pemikiran-pemikiran hukum dipandang sebagai pemikiran yang bersifat transformatif. Artinya pemikiran transformatif bukan

13 Sudikno Mertokusumo, Penemuan Hukum Sebuah Pengantar, (Yogyakarta: Liberty, 1996), hlm. 4. 14 Ibid., hlm. 11.

15 Teori hukum pembangunan yang berkembang pada tahun 1970-an dalam tataran konseptual sebenarnya sudah bagus yang dikonkretkan melalui perumusan dalam garis-garis besar haluan negara. Dalam konteks substansi peraturan perundang-undangan di bidang lingkungan hidup dan sumber daya alam hendaknya mampu menyelesaikan permasalahan lingkungan hidup secara nasional. Permasalahan lingkungan hidup bukannya berkurang, malah justru bertambah karena akibat manusia yang eksploitatif terhadap pengelolaan sumber daya alam, Terlebih, karakter pemerintahan tidak mendukung adanya konsep hukum sebagai sarana pembaharuan masyarakat. Namun terjadi konfigurasi politik dan hukum, sehingga dipengaruhi oleh karakter pemerintahan di zaman orde baru, sehingga substansi hukum pembangunan atau sebagai sarana pembaharuan masyarakat masih jauh dari harapan untuk diwujudkan dalam kenyataan. Hal tersebut dikarenakan pemerintahan orde baru yang sangat otoriter. Konfigurasi politik dan hukum tersebut pernah dijadikan sebagai bahan kajian disertasi Mahfud MD tentang politik hukum di Indonesia. 
hanya menyentuh aspek-aspek normatif dan doktrinal semata-mata, melainkan berusaha mentransformasikan fenomena-fenomena hukum dari aras empirik tentang keharusan untuk membicarakan hukum dalam konteks masyarakatnya yang dikonstruksikan ke dalam tataran teoritik-filosofis. ${ }^{16}$

Secara konstitusionalitas, penguasaan sumber daya alam oleh negara, sebagaimana diatur dalam UUD 1945 tidak dapat dipisahkan dengan tujuan dari penguasaan tersebut, yaitu guna mewujudkan sebesar-besar kemakmuran rakyat. Keterkaitan penguasaan oleh negara untuk kemakmuran rakyat, menurut Bagir Manan akan mewujudkan kewajiban negara dalam hal: ${ }^{17}$

a. Segala bentuk pemanfaatan (bumi dan air) serta hasil yang didapat (kekayaan alam), harus secara nyata meningkatkan kemakmuran dan kesejahteraan masyarakat;

b. Melindungi dan menjamin segala hak-hak rakyat yang terdapat didalam atau di atas bumi, air, dan berbagai kekayaan alam tertentu yang dapat dihasilkan secara langsung atau dinikmati langsung oleh rakyat;

c. Mencegah segala tindakan dari pihak manapun yang akan menyebabkan rakyat tidak mempunyai kesempatan atau akan kehilangan haknya dalam menikmati kekayaan alam.

Pembangunan ekonomi nasional maupun lokal sebagai implementasi dari Pasal 33 ayat (3) UUD 1945 dimana terdapat hak penguasaan negara atas sumber daya alam, diikuti oleh ayat ke (4) dengan memerhatikan beberapa prinsip, diantaranya keadilan, berwawasan lingkungan dan keberlanjutan. Kebijakan di sektor lingkungan hidup dan sumber daya alam dalam bentuk perundangundangan lingkungan hidup telah mengalami dua kali revisi, yakni UndangUndang Nomor 23 tahun 1997 tentang Pengelolaan Lingkungan Hidup, sebagai hasil dari revisi Undang-Undang Nomor 2 tahun 1984 tentang KetentuanKetentuan Pokok Pengelolaan Lingkungan Hidup. Kemudian dari UndangUndang Nomor 23 tahun 1997 terakhir diubah menjadi Undang-Undang Nomor

16 Khudzaifah Dimyati, Teorisasi Hukum Studi tentang Perkembangan Pemikiran Hukum di Indonesia 1945-1990, Cet. I, (Surakarta: Muhammadiyah University Press, 2004), hlm. 161-162.

17 Bagir Manan, Pertumbuhan dan Perkembangan Konstitusi Suatu Negara, (Bandung: Mandar Maju, 1995), hlm. 17. 
32 tahun 2009 tentang Perlindungan dan Pengelolaan Lingkungan Hidup. Semangat yang dibawa undang-undang perubahan tersebut sama dalam konteks pelestarian lingkungan. Selain itu, judul undang-undang mengalami perubahan pula hingga yang terakhir terkandung spirit perlindungan dan spirit pengelolaan. Undang-Undang No. 32 Tahun 2009 mengatur keterpaduan sebagai pedoman dalam penerbitan, pelaksanaan dan pengawasan izin bidang lingkungan hidup. ${ }^{18}$ Selain itu, Undang-Undang Nomor 32/2009 juga disebut sebagai undang-undang payung (umbrella lex) atau perundang-undangan lingkungan hidup yang umum (general environmental law). Instrumen-instrumen tersebut memuat hal-hal yang utuh dan menyeluruh berkaitan dengan perlindungan dan pengelolaan lingkungan hidup. Undang-undang payung tersebut dapat diartikan memayungi kebijakan pengaturan (undang-undang) yang bersifat sektoral.

Sebagai sebuah diagnosa awal, teori hukum pembangunan di masa orde baru lebih didominasi oleh kepentingan-kepentingan politik daripada semangat yang dibawa teori hukum pembangunan yang tertuang didalam GBHN, merupakan sebuah wacana tentang haluan pembangunan negara Republik Indonesia yang dibuat MPR lalu dilaksanakan dengan sebaik baiknya oleh presiden. Isi wacana yang sudah tersemat didalam GBHN tidak diperbolehkan bersimpangan atau bertentangan dan berbeda tujuan dengan UUD 1945. Fungsinya, pertama, sebagai visi dan misi rakyat Indonesia yang ditujukan untuk rencana pembangunan nasional dimana proses pembangunan yang akan dijalankan harus sesuai dengan apa yang dibutuhkan masyarakat secara merata adil dan makmur, dan kedua,

18 Dalam konteks peraturan perundangan lingkungan hidup dan sumber daya alam, instrumen lingkungan hidup erat kaitannya dengan kebijakan publik. Hukum dalam bentuk peraturan adalah perwujudan dari kebijakan publik penguasa, dan kebijakan publik itu sendiri merupakan proses politik, karena itu kebijakan publik tidak dapat dilepaskan dari isu-isu lingkungan politik. Lihat: Sigler, Jay A. dan Benyamin R. Beede, The Legal Sources of Public Policy, (Toronto: Lexington Books, 1978), hlm. 3. Hukum adalah produk politik, karena fungsi dan peran hukum sangat dipengaruhi dan seringkali diintervensi oleh kekuatan politik. Hukum sebagai perwujudan dari kebijakan publik adalah peraturan, karena itu peraturan juga sangat dipengaruhi oleh paradigma atau cara pandang penguasa terhadap hukum. Moh. Mahfud MD., Pergulatan Politik dan hukum di Indonesia, (Yogyakarta: Gama Media, 1999), hlm. v-viii. Penguasa memandang hukum sebagai alat rekayasa sosial, maka penguasa akan mengambil kebijakan publik yang kemudian diwujudkan menjadi peraturan-peraturan yang dapat digunakan untuk menciptakan sistem sosial yang dapat mengatur dan mengendalikan masyarakat. bandingkan dengan: Nonet, Philippe and Philip Selznick, terj., Hukum dan Masyarakat Dalam Transisi Menuju Hukum yang responsif, (Jakarta: Media Nusantara, 2001), hlm. 28. 
pembanguanan nasional yang dilaksanakan hanya semata mata dari rakyat, oleh rakyat dan untuk kepentingan rakyat; dan kedua, pelaksanaannya mencakup beberapa aspek penting yaitu aspek kehidupan berbangsa, politik, sosial budaya, pertahaanan keamanan dan ekonomi, dimana dilakuakan dengan memperkuat manfaat dari sumber daya manusia, sumber daya alam dan memperkuat ketahanan nasional secara merata.

Budiono Kusumohamidjojo ${ }^{19}$ menyoroti dengan tajam mengapa Roberto Mangabeira Unger mengamati bahwa hukum itu senantiasa merupakan bulanbulanan perebutan kekuasaan dalam masyarakat. seperti pemahaman Marx, hukum itu semata-mata alat di tangan yang berkuasa untuk mempertahankan kedudukan nikmat mereka. Hukum pada akhirnya adalah realisasi dari politik, hukum itu tidaklah bersifat bebas nilai. Pada akhirnya tidak dapat terhindarkan bahwa 'hukum adalah politik', tetapi tidaklah sekaligus niscaya bahwa 'politik adalah hukum'. ${ }^{20}$ Studi kritik hukum (critical legal studies) versi Unger dan kelanggengan ruang sosial yang tunduk pada dominasi hegemonial yang bersandar pada positivisme hukum.

Penulis menilai bahwa fenomena pengembangan hukum pembangunan masa masa orde baru yang secara eksplisit tertanam didalam GBHN ternyata tidak diikuti dengan kebijakan-kebijakan yang dikeluarkannya, sehingga tidak ada garis pemisah antara politik dan hukum. Alam pemikiran studi hukum kritis (critical legal studies) melihat bahwa hukum pembangunan pada masa itu berorientasi pada kelanggengan status quo, dan kesetiaan terhadap hukum yang represif, yakni kebijakan hukum tidak memerhatikan kebutuhan-kebutuhan dan perubahan di masyarakat, khususnya dinamika isu lingkungan hidup yang semakin kompleks, sehingga kerusakan dan atau pencemaran lingkungan sedemikian masifnya. Pembangunan hukum dan masyarakat ternyata tidak memberikan pengaruh yang signifikan, karena tidak didukung oleh rezim yang lebih mengedepankan politik dan ekonomi.

Studi hukum kritis dalam konteks kebijakan hukum pembangunan di sektor lingkungan hidup menyoroti isu-isu lingkungan baik kerusakan hutan,

19 Budiono Kusumohamidjojo, Cet. I, Teori Hukum, Dilema antara Hukum dan Kekuasaan, (Bandung: Penerbit Yrama Widya), 2016, hlm. 217.

20 Roberto M. Unger, Gerakan Hukum Kritis, (Critical Legal Studies), diterjemahkan oleh Ifdhal Kasim, (Jakarta: ELSAM), 1999, hlm. 23. 
pencemaran sungai, industrialisasi yang berimbas pada pencemaran lingkungan, serta pengambilan keputusan dan kebijakan negara didominasi oleh kelompok kapitalis. Ditegaskan lagi, secara radikal, gerakan studi hukum kritis menggugat teori, doktrin atau asas-asas seperti netralitas hukum (neutrality of law), otonomi hukum (autonomy of law), dan pemisahan hukum dengan politik (law politics distinction) ${ }^{21}$ Sebagai contoh lain dominasinya kekuasaan/politik dalam undangundang pertama kali lingkungan hidup di masa orde baru, yakni semangat perubahan sosial dan pembaharuan masyarakat sebagaimana dinyatakan eksplisit melalui GBHN di sektor pengelolaan lingkungan hidup melalui Undang-Undang Nomor 2 tahun 1984 tentang Pokok-pokok Pengelolaan Lingkungan Hidup, dalam praktik kekuasaan eksekutif terjadi ego sektoral diantara kementerian atau lembaga untuk menangani permasalahan pencemaran atau kerusakan lingkungan, penaatan terhadap instrumen lingkungan hidup lemah, dan berbagai macam sanksi lingkungan hidup, antara lain sanksi administrasi berupa teguran hingga pencabutan izin usaha, dan sanksi pidana ternyata tidak cukup memberikan pengaruh yang signifikan. Dua kali perubahan Undang-Undang Nomor 32 tahun 2009 tentang Perlindungan dan Pengelolaan Lingkungan Hidup menjadi faktor penentu keberhasilan kebijakan pembangunan hukum lingkungan yang berorientasi pada kelestarian lingkungan ditengah maraknya investasi saat ini di berbagai sektor, diantaranya perkebunan, kehutanan, dan pertambangan. Tolok ukurnya adalah pelaku usaha taat terhadap instrumen perizinan lingkungan hidup dan ketegasan pemerintah dalam memberikan sanksi.

Permasalahan yang substansial tersebut diikuti pula oleh ego sektoral diantara kementerian atau lembaga yang memiliki titik persinggungan. Misalnya terdapat persinggungan tugas antara Kementerian Lingkungan Hidup dan Kehutanan serta Kementerian Agraria dan Tata Ruang/Badan Pertanahan Nasional. Empat permasalahan utama terkait agraria dan tata ruang di Indonesia, yakni ketidakpastian hukum atas penguasaan, pemilikan, penggunaan, dan pemanfaatan tanah, ketimpangan penguasaan tanah, sengketa, dan konflik pertanahan yang berkepanjangan serta konflik tata ruang yang menghambat pembangunan. Berdasarkan data Kementerian Lingkungan Hidup dan Kehutanan, terdapat 13,1

21 W. Friedmann, Teori dan Filasafat Hukum; Susunan I, (Legal Theory), terjemahan: Mohamad Arifin, Cetakan Kedua, (Jakarta: PT. Raja Grafindo Perkasa), 1993, hlm.169-200. 
juta hektare hutan produksi yang bisa dikonversi di seluruh daerah di Indonesia. Dari jumlah tersebut, sekitar 6,6 juta ha sudah dipakai untuk kebun. Lahan selebihnya yang dapat dimanfaatkan masyarakat sebanyak 4-5 juta ha. ${ }^{22}$ Selain itu, termasuk juga Kementerian Energi dan Sumber Daya Mineral dan Kementerian Pekerjaan Umum dan Perumahan Rakyat.

Dari dinamika legislasi tersebut, dapat diidentifikasi bahwa teori hukum pembangunan pada awal kelahirannya tidak mendapatkan dukungan oleh karakter pemerintahan yang represif dan otoriter. Hukum itu senantiasa merupakan alat perebutan kekuasaan dalam masyarakat, yakni dominasinya kekuasaan/politik dalam undang-undang lingkungan hidup pertama kali di masa orde baru, yakni semangat perubahan sosial dan pembaharuan masyarakat dalam desain Garis-Garis Besar Haluan Negara di sektor pengelolaan lingkungan hidup yang dikonkretkan ke dalam Undang-Undang Nomor 2 tahun 1984 tentang Pokok-pokok Pengelolaan Lingkungan Hidup dan Undang-Undang Nomor 23 tahun 1997 tentang pengelolaan lingkungan hidup. Perjalanan kedua regulasi tersebut melahirkan kekuasaan yang represif, ego sektoral antar kementerian atau lembaga dalam menangani masalah pencemaran atau kerusakan lingkungan dan tidak tegas dalam memberikan sanksi kepada pelaku perusakan lingkungan, yakni kementerian lingkungan hidup, kementerian kehutanan, dan kementerian agraria yang selalu tumpang tindih kewenangan dalam aspek perizinan. Sedangkan dalam pengembangan teori hukum pembangunan pasca reformasi terkait kebijakan pengelolaan lingkungan hidup adanya menunjukkan transparansi dan peran publik dalam pembuatan kebijakan melalui Undang-Undang Nomor 32 tahun 2009 tentang Perlindungan dan Pengelolaan Lingkungan Hidup. Selain itu, teori hukum pembangunan pasca reformasi akan memiliki daya laku yang efektif disaat masyarakat terlibat dan ikut serta dalam proses penyusunan dokumen lingkungan

22 Lihat: http://www.republika.co.id/berita/koran/halaman-1/17/01/06/ojcjg640-tekanego-sektoral, diakses pada tanggal 03 Februari 2018. 
dan aktif menyuarakan hak-hak atas lingkungannya. ${ }^{23}$

Kebijakan pengelolaan lingkungan tidak lepas dari persoalan penataan ruang. Pengertian penataan ruang adalah proses yang meliputi perencanaan, pemanfaatan dan pengendalian pemanfaatan ruang. ${ }^{24}$ Mengacu pada pengertian ini, penataan ruang semestinya menjadi wadah bagi kegiatan pembangunan yang memanfaatkan ruang, sehingga penataan ruang dapat menjadi acuan dan pedoman bagi perumusan kebijakan pembangunan sektor dan daerah. ${ }^{25}$ Keterkaitan perencanaan tata ruang dan pembangunan berkelanjutan merupakan suatu aksioma, yakni sesuatu yang sudah pasti dan tidak memerlukan pembuktian serta telah diketahui oleh masyarakat umum. Meskipun aksiomatik, namun kita memperoleh pemahaman tambahan dari kenyataan tersebut, yakni praktik pelaksanaan sistem perencanaan tata ruang yang memengaruhi tujuan akhir pembangunan berkelanjutan, yakni proses pembangunan berlangsung secara berlanjut dan didukung sumber alam yang ada dengan kualitas lingkungan dan manusia yang semakin berkembang dalam batas daya dukung lingkupannya. Pembangunan akan memungkinkan generasi sekarang meningkatkan kesejahteraannya, tanpa mengurangi kemungkinan bagi generasi masa depan untuk meningkatkan kesejahteraannya. ${ }^{26}$ Jika pelaksanaan sistem perencanaan tata ruang berjalan dengan baik, maka tujuan pembangunan

23 Didalam Pasal 70 undang-undang nomor 32 tahun 2009 tentang perlindungan dan pengelolaan lingkungan hidup dinyatakan secara eksplisit bahwa: (1) Masyarakat memiliki hak dan kesempatan yang sama dan seluas-luasnya untuk berperan aktif dalam perlindungan dan pengelolaan lingkungan hidup. (2) Peran masyarakat dapat berupa: a. pengawasan sosial; b. pemberian saran, pendapat, usul, keberatan, pengaduan; dan/atau c. penyampaian informasi dan/atau laporan. (3) Peran masyarakat dilakukan untuk: a. meningkatkan kepedulian dalam perlindungan dan pengelolaan lingkungan hidup; b. meningkatkan kemandirian, keberdayaan masyarakat, dan kemitraan; c. menumbuhkembangkan kemampuan dan kepeloporan masyarakat; d. menumbuhkembangkan ketanggapsegeraan masyarakat untuk melakukan pengawasan sosial; dan e. mengembangkan dan menjaga budaya dan kearifan lokal dalam rangka pelestarian fungsi lingkungan hidup.

24 Lihat: Pasal 1 angka 5 Undang-Undang Nomor 26 tahun 2007 tentang Penataan Ruang

25 Didalam Pasal 14 Undang-Undang Nomor 32 tahun 2009 tentang Perlindungan dan Pengelolaan Lingkungan Hidup berkenaan dengan pencegahan, salah satu instrumen pencegahan pencemaran dan/atau kerusakan lingkungan hidup adalah tata ruang. Selain itu, Pasal 15 undang-undang tersebut mengatur tentang Kajian Lingkungan Hidup Strategis (KLHS) juga mengatur mengenai tata ruang sebagai dasar penyusunan KLHS oleh pemerintah dan pemerintah daerah, Pasal 15 ayat (2) huruf a dinyatakan: Rencana Tata Ruang Wilayah (RTRW) beserta rencana rincinya, Rencana Pembangunan Jangka Panjang (RPJP), dan Rencana Pembangunan Jangka Menengah (RPJM) nasional, provinsi, dan kabupaten/kota.

26 Otto Soemarwoto, Pembangunan Berkelanjutan: Antara Konsep dan Realitas, Bandung: Departemen Pendidikan Nasional Universitas Padjajaran Bandung, 2006, hlm. 22. 
berkelanjutan akan tercapai, demikian pula sebaliknya. ${ }^{27}$

Kebijakanpengelolaanlingkunganhidup pascareformasidalampengembangan teori hukum pembangunan terejawantahkan dalam melalui Undang-Undang Nomor 32 Tahun 2009 tentang Perlindungan dan Pengelolaan Lingkungan Hidup, yang dipandang cukup komprehensif bila dibandingkan dengan produk hukum sebelumnya, dimulai dari instrumen perizinan lingkungan, peran serta masyarakat, asas-asas, sanksi-sanksi yang tegas. Tidak hanya pelaku usaha, tetapi pemerintah daerah dapat juga dikenakan sanksi oleh pusat, hingga ke persoalan penyelesaian sengketa lingkungan hidup. Instrumen terpenting lainnya dalam undang-undang payung (induk) yaitu terkait dengan Analisis Mengenai Dampak Lingkungan, yang dapat ditemukan di dalam Pasal 22 Paragraf 5 Undang-Undang Nomor 32 tahun 2009 tentang Perlindungan dan Pengelolaan Lingkungan Hidup adalah kajian mengenai dampak penting suatu usaha dan/atau kegiatan yang direncanakan pada lingkungan hidup yang diperlukan bagi proses pengambilan keputusan tentang penyelenggaraan usaha dan/atau kegiatan. Pasal 33 dari Undang-Undang Nomor 32 tahun 2009 tentang Perlindungan dan Pengelolaan Lingkungan Hidup menyatakan bahwa ketentuan lebih lanjut mengenai amdal sebagaimana dimaksud dalam Pasal 22 sampai dengan Pasal 32 diatur dalam

27 Terdapat tolok ukur pencapaian keberhasilan tujuan pembangunan berkelanjutan dengan penataan ruang. Ruang yang baik dan sesuai dengan perkembangan karena, dampak dari pembangunan akan mengakibatkan perubahan besar baik terhadap struktur ekonomi, sosial, fisik, wilayah, pola konsumsi, sumber alam dan lingkungan hidup, tekhnologi, maupun perubahan terhadap sistem nilai dan kebudayaan. Di sisi lain, perubahan besar itu sendiri membawa pengaruh yang tidak diharapkan dan tidak direncanakan, terutama dalam bentuk dampak negatif terhadap lingkungan hidup. Sesungguhnya, terjadinya kerusakan lingkungan lebih banyak disebabkan oleh, sikap penghilafan pembangunan yang kurang menyadari pentingnya segi lingkungan hidup. Pembangunan yang dilakukan pada saat ini, adalah untuk meningkatkan kesejahteraan masyarakat, namun dampak negatif dari pembangunan sering terjadi pada lingkungan akibat penataan ruang yang kurang baik dan tidak diharmonisasikan dengan lingkungan. Akibatnya menimbulkan masalah-masalah baru yang justru dapat memperburuk kehidupan masyarakat. Karena saat ini kebijakan penataan ruang telah menjadi kewenangan pemerintah daerah masing-masing, maka usaha meminimalisasi dampak negatif akibat pembangunan perlu dilakukan dengan pengaturan penataan ruang yang baik, karena penataan ruang akan menjadi penentu kualitas lingkungan. 
Peraturan Pemerintah No. 27 tahun 2012 tentang Izin Lingkungan. ${ }^{28}$ Di dalam Pasal 4 Peraturan Pemerintah tersebut, Amdal disusun oleh pemrakarsa pada tahap perencanaan suatu usaha atau kegiatan yang wajib sesuai dengan rencana tata ruang, apabila tidak sesuai dengan rencana tata ruang, maka dokumen Amdal tidak dapat dinilai dan wajib dikembalikan kepada pemrakarsa.

Implementasi teori hukum pembangunan pasca reformasi ditandai dengan keterlibatan atau peran serta masyarakat dalam proses penyusunan dokumen lingkungan. Hal tersebut dapat dilihat dalam penyusunan dokumen lingkungan hidup yang lebih teknis, diatur di dalam Peraturan Menteri. ${ }^{29}$ Sedangkan khusus mengenai pengikutsertaan masyarakat dalam penyusunan Amdal, sebagaimana dinyatakan dalam Pasal 9 ayat (1) PP No. 27 tahun 2012, yakni: a. masyarakat yang terkena dampak; b. pemerhati lingkungan hidup; c. dan atau yang terpengaruh atas segala bentuk keputusan dalam proses Amdal, diatur lebih teknis di dalam Peraturan Menteri berkaitan dengan tata cara pengikutsertaan masyarakat dalam penyusunan Amdal. ${ }^{30}$

28 Peraturan Pemerintah yang dimaksud adalah Peraturan Pemerintah No. 27 tahun 2012 tentang Izin Lingkungan. PP tersebut sebagai perubahan dari PP No. 27 tahun 1999 tentang Analisis Mengenai Dampak Lingkungan. Di dalam Pasal 74 PP No. 27 tahun 2012 tentang Izin Lingkungan dinayatakan: Pada saat Peraturan Pemerintah ini mulai berlaku, Peraturan Pemerintah Nomor 27 Tahun 1999 tentang Analisis Mengenai Dampak Lingkungan Hidup (Lembaran Negara Republik Indonesia Tahun 1999 Nomor 59, Tambahan Lembaran Negara Republik Indonesia Nomor 3838) dicabut dan dinyatakan tidak berlaku.

29 Peraturan Menteri yang dimaksud adalah Peraturan Menteri Negara Lingkungan Hidup Republik Indonesia Nomor 16 tahun 2012 tentang Pedoman Penyusunan Dokumen Lingkungan Hidup, sebagai pelaksana dari Pasal 6 dan Pasal 16 PP No. 27 tahun 2012 tentang Izin Lingkungan. Dalam Peraturan Menteri ini, Pasal 10 menyatakan: Pada saat Peraturan Menteri ini mulai berlaku:

a. Peraturan Menteri Negara Lingkungan Hidup Nomor 08 Tahun 2006 tentang PedomanPenyusunan Dokumen Analisis Mengenai Dampak Lingkungan Hidup; dan

b. Peraturan Menteri Negara Lingkungan Hidup Nomor 13 Tahun 2010 tentang Upaya Pengelolaan Lingkungan Hidup dan Upaya Pemantauan Lingkungan Hidup dan Surat Penyataan Kesanggupan Pengelolaan dan Pemantauan Lingkungan Hidup, dicabut dan dinyatakan tidak berlaku.

30 Peraturan Menteri dimaksud adalah Peraturan Menteri Negara Lingkungan Hidup Republik Indonesia No. 17 tahun 2012 tentang Pedoman Keterlibatan Masyarakat Dalam Proses Analisis Dampak Lingkungan Hidup dan Izin Lingkungan, untuk melaksanakan Pasal 9 ayat (6) dan Pasal 52 PP No. 27 tahun 2012. Adapun Muatan Pedoman keterlibatan masyarakat dalam proses Analisis Mengenai Dampak Lingkungan dan Izin Lingkungan dinyatakan dalam Pasal 4 Permen. Lingkungan Hidup No. 17 tahun 2012: a. pendahuluan; b. tata cara pengikutsertaan masyarakat dalam proses analisis mengenai dampak lingkungan; dan c. tata cara pengikutsertaan masyarakat dalam proses izin lingkungan. 
Sistem Amdal di Indonesia telah ada sekitar 20 tahun lamanya. Pada akhir tahun 2003, Kementerian Lingkungan Hidup (KLH) meluncurkan suatu tahap lanjutan dari reformasi sistem kajian dampak lingkungan. Revitalisasi Amdal bertujuan untuk menjawab berbagai tantangan, misalya Bank Dunia telah menyediakan bantuan dari revitalisasi Amdal melalui riset untuk mengadaptasikan peraturan lingkungan hidup yang berubah. Berdasarkan hasil studi yang dilakukan oleh Helmi, ${ }^{31}$ di tingkat Provinsi Jawa Barat dan Kalimantan Timur dengan melihat berbagai sistem Amdal ada pada saat ini dapat divariasikan untuk memungkinkan berbagai perbedaan di dalam prioritas lingkungan yang ada dari satu daerah ke daerah lain atas praktik Amdal yang baik.

Amdal dan UKL-UPL merupakan salah satu syarat untuk mendapatkan Izin Lingkungan. ${ }^{32}$ Pada dasarnya, proses penilaian Amdal atau pemeriksaan UKL-UPL merupakan satu kesatuan dengan proses permohonan dan penerbitan izin lingkungan. Dengan dimasukkannya Amdal dan UKL-UPL dalam proses perencanaan usaha dan/atau kegiatan, maka Menteri, Gubernur, atau Bupati/ Walikota sesuai dengan kewenangannya mendapatkan informasi yang luas dan mendalam terkait dengan dampak lingkungan yang mungkin terjadi dari suatu rencana usaha dan/atau kegiatan tersebut dan langkah-langkah pengendaliannya, baik dari aspek teknologi, sosial, dan keagamaan. ${ }^{33}$ Tujuan diterbitkannya izin lingkungan antara lain untuk memberikan perlindungan terhadap lingkungan hidup yang lestari dan berkelanjutan, meningkatkan upaya pengendalian usaha dan/atau kegiatan yang berdampak negatif pada lingkungan hidup. Disamping itu juga untuk memberikan kejelasan prosedur, mekanisme dan koordinasi antar instansi dalam penyelenggaraan perizinan untuk usaha dan/atau kegiatan bagi

31 Helmi, Hukum Perizinan Lingkungan Hidup, Cet. I, (Jakarta: Sinar Grafika, 2012), hlm. 132.

32 Dalam Pasal 36 UU No. 32 tahun 2009 tentang Perlindungan dan Pengelolaan Lingkungan Hidup, mengatur tentang izin lingkungan. Dinyatakan: ayat (1) Setiap usaha dan/atau kegiatan yang wajib memiliki amdal atau UKL-UPL wajib memiliki izin lingkungan. ayat (2) Izin lingkungan sebagaimana dimaksud pada ayat (1) diterbitkan berdasarkan keputusan kelayakan lingkungan hidup sebagaimana dimaksud dalam Pasal 31 atau rekomendasi UKL-UPL. Ayat (3) Izin lingkungan sebagaimana dimaksud pada ayat (1) wajib mencantumkan persyaratan yang dimuat dalam keputusan kelayakan lingkungan hidup atau rekomendasi UKL-UPL. Ayat (4) Izin lingkungan diterbitkan oleh Menteri, gubernur, atau bupati/ walikota sesuai dengan kewenangannya.

33 Bachrul Amiq, Penerapan Sanksi Administrasi dalam Hukum Lingkungan, Cet. I, (Yogyakarta: Laksbang Mediatama, 2013), hlm. 86. 
setiap pelaku usaha. ${ }^{34}$

Satjipto Rahardjo juga menekankan bahwa fungsi hukum sebagai sarana social engineering lebih bersifat dinamis, yaitu hukum digunakan sebagai sarana untuk melakukan perubahan-perubahan didalam masyarakat. Jadi dalam hal ini, hukum tidak sekedar meneguhkan pola-pola yang memang telah ada di dalam masyarakat untuk menciptakan hal-hal atau hubungan-hubungan yang baru. Perubahan ini hendak dicapai dengan cara memanipulasi ${ }^{35}$ keputusan-keputusan yang akan diambil oleh individu-individu dan mengarahkannya kepada tujuantujuan yang dikehendaki. Demokrasi yang sedang membangun di masa transisi saat ini membuka peluang keterlibatan masyarakat dalam proses pembuatan atau perumusan kebijakan publik di sektor usaha dalam kaitannya dengan persoalan lingkungan hidup dan sumber daya alam. Pasca reformasi, hukum sebagai sarana pembaharuan masyarakat hendaknya diorientasikan kepada kebutuhankebutuhan masyarakat dan peran serta masyarakat dalam proses perumusan kebijakan di sektor lingkungan hidup. Teori hukum pembangunan harus mampu menjawab sejumlah kasus belakangan ini diantaranya illegal loging, pembakaran hutan dan lahan, ${ }^{36}$ reklamasi pantai dengan penolakan warga, pembangunan pabrik semen yang merusak lingkungan di kawasan lindung dan telah ditetapkan berdasarkan Perda Rencana Tata Ruang Kota dan Wilayah Kabupaten Rembang

$34 \quad$ Ibid., hlm. 87.

35 Artinya manipulasi ini dapat digunakan dengan berbagai macam cara, misalnya dengan memberikan ancaman pidana, insentif, dan sebagainya. Hubungan antara hukum dan perubahan sosial adalah jelas sekali, karena hukum disini justru dipanggil untuk mendatangkan perubahan-perubahan didalam masyarakat. Ibid., hlm. 126.

36 Lihat: Presiden dinyatakan bersalah terkait kebakaran hutan di indonesia, http://regional. kompas.com/read/2017/03/23/17590361/presiden.dinyatakan.bersalah.terkait.kebakaran. hutan.di.indonesia, diakses pada tanggal 24 Maret 2017. 


\section{Provinsi Jawa Tengah Nomor 14 Tahun 2011, ${ }^{37}$ serta aktivitas pertambangan yang mendapatkan perlawanan dengan masyarakat adat/tradisional.}

37 Dalam kasus masyarakat petani di pegunungan kendeng Kabupaten Rembang Jawa Tengah, kawasan pegunungan kendeng ditetapkan pemerintah sebagai lokasi pendirian pabrik semen gresik (sekarang menjadi PT Semen Indonesia, tbk. persero), didirikan sejak tahun 2010. Kasus ini terus-menerus muncul di media, menyedot perhatian publik dan menjadi isu nasional. Melalui proses litigasi, pihak perwakilan Masyarakat Rembang, Tim Advokasi Peduli Lingkungan Hidup, dan Yayasan Wahana Lingkungan Hidup Indonesia (WALHI), mengajukan upaya Hukum Peninjauan Kembali pada perkara Putusan PK No. 99/PK/TUN/ 2016 dengan mengajukan Novum baru, adapun Amar Putusanya Majelis Hakim PK menyatakan mengabulkan permohon PK Masyarakat Rembang, Tim Advokasi Peduli Lingkungan Hidup, dan Yayasan Wahana Lingkungan Hidup Indonesia (WALHI), pada putusan PK No. 99/ PK/TUN/ 2016 memerintahkan juga agar Gubernur Jawa Tengah mencabut Surat Keputusan Gubernur Jawa Tengah Nomor 660.1/17 tahun 2012 tertanggal 7 Juni 2012. Ketentuan mengenai perintah MA tersebut telah dilakukan pencabutan oleh Gubernur Jawa Tengah yakni dengan dicabutnya Surat Keputusan Gubernur Jawa Tengah Nomor 660.1/17 tahun 2012. Namun, kendatinya Gubernur Jawa Tengah menerbitkan keputusan baru dengan dikeluarkannya Surat No. 660.1/ 6 tahun 2017 tentang Penerbitan Izin Lingkungan Semen di Rembang, sebagai tindak lanjut dari rekomendasi Komisi Penilai Amdal (KPA), yang mengizinkan PT. Semen Indonesia melakukan penambangan pabrik di Rembang, Jawa Tengah tersebut. Meskipun demikian, kegiatan pertambangan semen hingga saat ini belum beroperasi dikarenakan masih terjadi penolakan warga. Bahkan, sejak hari Kamis, tanggal 16 Maret 2017 warga kendeng berdatangan di Jakarta melakukan aksi pengecoran kaki dengan semen berlokasi di sebrang kantor presiden hingga berlangsung 2 minggu. Dalam aksi tersebut, terjadi insiden meninggalnya Ibu Patmi salah seorang warga kendeng yang pada saat itu kakinya masih dicor semen, dimana sebelumnya telah dilakukan pemeriksaan oleh dokter, diduga terkena serangan jantung pada tanggal 21 Maret 2017. Oleh para aktivis lingkungan, Ibu Patmi disebut sebagai pahlawan kartini kendeng yang berjuang melawan rezim otoritarianism dan justru kontradiktif terhadap program pemerintah yang selalu menyatakan tindakan untuk ikut menjadi resolusi sejati dari krisis perubahan iklim dan hilangnya keanekaragaman hayati, menegakkan hukum dan melakukan pembangunan dari pinggiran. 


\section{Rekonstruksi hukum pembangunan dalam kebijakan pengaturan lingkungan hidup dan sumber daya alam}

Dalam kaitannya dengan hierarkinorma ${ }^{38}$ hukum, Hans Kelsen mengemukakan teori mengenai jenjang norma hukum (stufentheorie). Kelsen berpendapat bahwa norma-norma hukum itu berjenjang-jenjang dan berlapis-lapis dalam suatu hierarki (tata susunan), dalam arti suatu norma yang lebih rendah berlaku, bersumber dan berdasar pada norma yang lebih tinggi, norma yang lebih tinggi berlaku, bersumber dan berdasar pada norma yang lebih tinggi lagi, demikian seterusnya sampai pada suatu norma yang tidak dapat ditelusuri lebih lanjut dan bersifat hipotesis dan fiktif, yakni norma dasar (Grundnorm) ${ }^{39}$

Menurut Bruggink sebagaimana dialihbahasakan oleh B. Arief Sidharta, ${ }^{40}$ bahwa orang berbicara tentang keberlakuan normatif suatu kaidah hukum, jika kaidah itu merupakan bagian dari suatu sistem kaidah hukum tertentu yang didalamnya kaidah-kaidah hukum itu saling menunjuk yang satu terhadap lainnya. Sistem kaidah hukum yang demikian itu terdiri atas suatu keseluruhan hierarkhi kaidah hukum khusus yang bertumpu pada kaidah-kaidah hukum umum. Didalamnya, kaidah hukum khusus yang lebih rendah diderivasi dari kaidah hukum umum yang lebih tinggi. Karena pada keberlakuan ini diabstraksi dari isi kaidah hukum, tetapi perhatian hanya diberikan pada tempat kaidah

38 Perkataan 'norm' (dalam bahasa-bahasa Barat) berasal dari bahasa latin "norma", dan di Jerman telah memperoleh sifat dari sebuah perkataan-pinjaman, yang menunjukkan terutama jika tidak secara eksklusif suatu ketertiban, preskripsi, atau perintah. Akan tetapi, hal memerintah adalah bukan satu-satunya fungsi dari sebuah norma. Memberikan kewenangan (authorising), mengizinkan dan penderogasian adalah juga fungsi-fungsi dari norma-norma. Menunjuk pada (merefer) norma-norma dari moralitas atau hukum sebagai preskripsi-preskripsi bagi tingkah lakubertimbal-balik antar manusia, dan dengan demikian berusaha untuk memunculkan (mengungkapkan) bahwa apa yang kita namakan "moralitas" atau "hukum" terdiri dari norma-norma, adalah suatu agregasi, atau sistem dari normanorma. Kita juga berbicara tentang "norma-norma" dari logika sebagai preskripsi-preskripsi bagi berpikir (menalar), tetapi asumsi bahwa asas-asas logikal yang demikian seperti hukum non-kontradiksi atau aturan-aturan inferensi mempunyai sifat dari norma-norma, bhwa logika sebagai sebuah ilmu (a science) berurusan dengan norma-norma sama sebagaimana etika dan ilmu hukummelakukannya adalah terbuka bagi perdebatan. Lihat: Hans Kelsen, Essays in Legal and Moral Philosophy, Hukum dan Logika, alih bahasa: B. Arief Sidharta, Cet. 2, (Bandung: PT Alumni, 2006), hlm. 1-2.

39 Kelsen, Hans, General Theory of Law and State, (New York: Russell \& Russell, 1945), hlm. 113.

40 Arief Sidharta, Refleksi Tentang Hukum, Alih Bahasa dari Bruggink dengan judul buku asli "Rechtsreflecties", Cet. 2, (Bandung: PT Citra Aditya, 1999), hlm. 150. 
hukum itu didalam sistem hukum, maka keberlakuan ini disebut juga keberlakuan formal. Dalam pendekatan keberlakuan kaidah hukum ini, maka dengan demikian tiap kaidah hukum harus diderivasi dari sistem hukum itu, tanpa memerhatikan isi kaidah hukum itu.

Konsistensi antar norma berdasarkan hierarkhi peraturan tersebut senada dengan kelompok positivis dari pemikiran H.L.A. Hart, ${ }^{41}$ sebagai tokoh aliran positivis berusaha menjelaskan perubahan hukum dalam kehidupan modern, dimana sebagian besar tatanan kehidupan masyarakat adalah hukum. Perubahan masyarakat atau kehidupan berdasarkan kepada 'primary rules of obligation' (hukum yang muncul alami) kepada 'secondary rules of obligations' (struktur hukum

41 Hart mendefinisikan hukum sebagai suatu sistem aturan-aturan primer dan aturan-aturan sekunder. aturan primer berhubungan dengan aksi-aksi yang harus dilakukan atau tidak boleh dilakukan oleh individu-individu, sedangkan aturan-aturan sekunder berhubungan dengan pembuatan, penafsiran, penerapan dan perubahan aturan-aturan primer, seperti misalnya aturan-aturan yang harus diikuti oleh pembentuk undang-undang, pengadilan, dan administrator pada saat mereka membuat, menafsirkan, dan menerapkan aturan-aturan (primer). Lihat: Hart, H.L.A., The Concept of Law, (London: Oxford University Press, 1972), p.77. 
perundang-undangan). ${ }^{42}$ Kendati peralihan kepada sistem hukum modern ${ }^{43}$ dapat disebut sebagai revolusi, tetapi kehadiran dan kekuatan dari tatanan masa lalu tidak sama sekali hilang. Hukum yang diorientasikan kepada pembaharuan masyarakat dalam perspektif Hart perlu adanya keseimbangan dengan primary rules of obligations (hukum yang muncul alami), dalam bentuk kearifan lokal, nilai-nilai, budaya hukum dan hukum yang ditemukan dan telah mendapatkan kesepakatan masyarakat tersendiri.

42 Seorang eksponen Critical Legal Studies (CLS) Roberto M. Unger lebih jauh menegaskan bahwa dengan lahirnya hukum modern, maka telah lahir suatu institusi yang benar-benar disebut hukum. Dengan demikian, bentuk dan sistem pada masa lalu yang juga disebut hukum, sebetulnya tidak layak disebut sebagai demkian. Hukum modern itulah yang boleh menyandang sebutan hukum, sehingga disebut 'the legal system', sedang yang pernah ada tidak layak untuk disebut demikian. Lihat: Unger, Roberto Mangabeira, Law and Modern Society, Toward a Criticism of Social Theory, (New Yok: The Free Press, 1976), hlm. 66-76. Hukum semakin menjadi tipe penataan masyarakat yang sangat khas (distinct), sejak kelahiran sistem hukum moder di dunia. Tidak ada sistem hukum lain yang layak disebut 'legal system', kecuali sistem hukum modern. Lihat: Satjipto Rahardjo, Lapisan-Lapisan Dalam Studi Hukum, Cet. I, (Malang: Bayumedia Publishing, 2009), hlm. 94.

43 Sistem hukum modern dicirikan oleh Marc Galanter sebagai berikut: (a) hukum uniform, terdiri dari peraturan-peraturan yang uniform dan tidak berbeda pula dengan penerapannya. Peraturan-peraturan yang sama dapat diterapkan bagi umat segala agama, warga semua suku bangsa, daerah kasta, dan golongan; (b) hukum transaksional, lebih cenderung untuk membagi hak dan kewajiban yang timbul dari transaksi dari pihak-pihak yang bersangkutan daripada mengumpulkan didalam himpunan yang tak berubah-ubah yang disebabkan oleh hal-hal yang menentukan diluar transaksi-transaksi tertentu; (c) hukum universal, cara-cara khusus pengaturan dibuat untuk memberikan contoh tentang suatu patokan yang sahih bagi penerapannya secara umum daripada menunjukkan sifat-sifatnya yang unik dan intuitif; (d) hierarki, terdapat suatu jaringan tingkat naik banding dan telaah ulang yang teratur untuk menjamin bahwa tindakan lokal sejalan dengan patokan nasional; (e) birokrasi, untuk menjamin adanya uniformitas, sistem hukum tersebut harus berjalan secara impersonal dengan mengikuti prosedur tertulis untuk masih-masing kasus dan memutuskan masing-masing kasus itu sejalan dengan peraturan yang tertulis pula; (f) rasionalitas, peraturan dan prosedur dapat dipastikan dari sumber tertulis dengan cara-cara yang dapat dipelajari dan disampaikan tanpa adanya bakat istimewa yang non rasional; (g) profesionalisme, sistem tersebut dikelola oleh orang-orang yang dipilih menurut persyaratan, yang dapat diuji untuk pekerjaan ini. persyaratan mereka ditentukan oleh penguasaannya atas cara-cara sistem hukum itu sendiri; (h) perantara, karena sistem itu menjadi lebih teknis dan lebih kompleks, maka ada perantara professional khusus diantara mahkamah pengadilan; (i) dapat diralat, tidak ada ketetapan hati didalam sistem prosedur itu. Sistem tersebut berisi kode biasa untuk merevisi peraturan-peraturan dan prosedur, agar memenuhi kebutuhan yang berubah-ubah atau untuk menyatakan kecenderungan yang berubah-ubah; (j) pengawasan politik, sistem demikian sangat berhubungan dengan negara yang memiliki persengketaan di kawasannya; dan (k) pembedaan., tugas untuk mendapatkan hukum dan menerapkannya pada kasus-kasus konkret dibedakan dari fungsi-fungsi kepemerintahan lainnya dalam hal personel dan teknik. Lihat: Galanter, Marc, "Hukum Hindu dan Perkembangan Sistem Hukum India Modern", dalam A.A.G. Peters dan Koesriani-Siswosoebroto (ed), Hukum dan Perkembangan Sosial, Buku Teks Sosiologi Hukum, Buku II, (Jakarta: Pustaka Sinar Harapan, 1988), hlm. 147-149. 
Pemikiran tentang hukum yang kemudian melahirkan positivisme, ${ }^{44}$ tidak dapat dipisahkan dari kehadiran negara modern sebelum abad ke-18, pikiran itu sudah hadir dan menjadi semakin kuat sejak kehadiran negara modern. Jauh sebelum tradisi untuk menuangkan atau menjadikan hukum positif itu, masyarakat lebih menggunakan apa yang disebut interactional law atau customary law. Akan tetapi, dengan semakin tidak sederhana lagi hubungan dan proses dalam masyarakat, maka semakin kuat tuntutan terhadap pemositifan tersebut atau terhadap the statutoriness of law. Hal ini karena dikehendaki adanya dokumen tertulis, bukti-bukti tertulis, untuk meyakini dan mendasari terjadinya proses atau transaksi hukum. Seperti diamati Roberto M. Unger, menyusul tipe hukum yang interaksional tersebut, datang fase hukum yang positif dan publik. Perkembangan tersebut mengiringi yang oleh Unger disebut sebagai tipe bureaucratic law. ${ }^{45}$

Penulis mengeksplorasi melalui gagasan diperlukannya rekonstruksi teori hukum pembangunan. Rekonstruksi tersebut dapat dimaknai sebagai penataan ulang atau menata kembali teori hukum pembangunan yang pada masa orde baru terejawantahkan ke dalam Garis-Garis Besar Haluan Negara (GBHN), untuk kemudian diterapkan era reformasi dalam konteks kebijakan (legal policy) perundang-undangan lingkungan hidup dan sumber daya alam. Semangat yang terkandung dalam teori hukum pembangunan ternyata tidak diikuti oleh semangat kekuasaan orde baru yang otoritarian dan represif, sehingga teori hukum pembangunan gagal diimplementasikan dengan baik dalam konteks kebijakan perundang-undangan lingkungan hidup dan sumber daya alam. Dalam permasalahan lingkungan muncul ego sektoral antar kelembagaan atau instansi pemerintahan, kelompok masyarakat sipil tidak berdaya melawan kekuasaan

44 Dalam pergulatan positivisme hukum yang lahir pada abad ke-18, terdapat dua bentuk: yaitu pertama, positivisme yuridis. Bahwa hukum dipandang sebagai suatu gejala tersendiri yang perlu diolah secara ilmiah. Tujuan positivisme adalah pembentukan struktur-struktur rasional sistem-sistem yuridis yang berlaku. Sebab, hukum dipandang sebagai hasil pengolahan sistem belaka, akibatnya, pembentukan hukum menjadi makin professional. Dalam positivism yuridis ditambahkan bahwa hukum adalah closed logical system. Artinya, peraturan dapat dideduksikan dari undang-undang yang berlaku tanpa perlu meminta bimbingan dari norma sosial, politik dan moral. Tokoh-tokohnya seperti R. von Jhering dan John Austin. Kedua, positivisme sosiologis, hukum ditanggapi sebagai terbuka bagi kehidupan masyarakat, yang harus diselidiki melalui metode-metode ilmiah. Tokoh yang mengawalinya adalah Auguste Comte, sebagai perintis positivism ini dengan menciptakan suatu ilmu pengetahuan antara hukum dan negara. Lihat: Theo Huijbers, Filsafat Hukum, (Yogyakarta: Kanisius, 1991), hlm. 32.

45 Roberto M. Unger, op.cit, hlm. 46. 
yang represif, meskipun pencemaran dan atau kerusakan lingkungan sedemikian parahnya.

Dalam kasus yang terjadi diSamarinda sebagai ibukota Kalimantan Timur yang $70 \%$ wilayahnya adalah wilayah pertambangan, ${ }^{46}$ warga Samarinda merasakan berbagai dampak terhadap lingkungan dan kesehatan mereka. Pembukaan tambang batubara sangat memengaruhi kerusakan lingkungan, karena pembukaan tambang batubara akan membuka lapisan permukaan dan dalam tanah yang akan meningkatkan hilangnya humus, erosi dan mengakibatkan sedimentasi berlebihan, sehingga meningkatkan peluang banjir. Pembukaan tambang batubara juga berakibat pada pencemaran air dan udara yang berdampak pada kesehatan masyarakat. Melihat kondisi yang demikian, interaksi hukum lokal dengan hukum negara melahirkan suatu penghindaran hukum lokal terhadap hukum negara dan terjadilah konflik.

Penyelesaian konflik ditengah kondisi lingkungan yang rusak, tidak adanya reklamasi pasca tambang dan gangguan kesehatan bagi masyarakat lokal, menjadi faktor penyebab dilakukannya gugatan class action oleh masyarakat. ${ }^{47}$ Gugatan ke pengadilan menjadi pilihan terakhir, seakan forum-forum mediasi gagal diterapkan pemerintah daerah terhadap kasus ini. Dalam kajian ICEL (Indonesian Center for Environmental Law), ${ }^{48}$ warga Samarinda melakukan gugatan kepada pemerintah untuk pemenuhan hak atas lingkungan hidup yang baik dan sehat. Kasus ini diputus dalam Putusan Pengadilan Negeri Kota Samarinda Nomor 55/Pdt.G/2013/PN Smda, dengan tergugat Walikota Samarinda, Menteri Energi dan Sumber Daya Mineral (ESDM), Gubernur Provinsi Kalimantan Timur, Kementerian Lingkungan Hidup dan DPRD Kota Samarinda. Warga Samarinda

46 Energy Today, “Jatam Kaltim: tambang batubara kurangi ruang hidup warga”, http://energytoday.com/2013/11/28/tambang-batubara-kurangi-ruang-hidup-warga/, diakses pada tanggal 2 Nopember 2016.

47 Dalam UU No. 32 tahun 2009 tentang Perlindungan dan Pengelolaan Lingkungan Hidup, terdapat 3 kelompok yang diberikan hak gugat, yakni pemerintah, masyarakat dan organisasi lingkungan hidup. Sebagai dasar hukumnya, hak gugat masyarakat diatur dalam Pasal 91 ayat (1) dinyatakan "masyarakat berhak mengajukan gugatan perwakilan kelompok untuk kepentingan dirinya sendiri dan/atau untuk kepentingan masyarakat apabila mengalami kerugian akibat pencemaran dan/atau kerusakan lingkungan hidup."

48 Rizkita Alamanda, Gugatan Warga Negara (Studi Kasus: Gerakan Samarinda Menggugat), dalam Jurnal Hukum Lingkungan Indonesia, Vol. I, Issue 2, Desember 2014, Jakarta: diterbitkan oleh Indonesian Center for Environmental Law (ICEL) Lembaga Pengembangan Hukum Lingkungan Indonesia, 2014, hlm. 118. 
menggugat pemerintah karena kelalaiannya untuk tidak dipenuhi kewajiban mereka dalam memberikan lingkungan yang baik dan sehat, dalam hal ini terkait dengan meningkatnya kerentanan warga Samarinda dalam menghadapi perubahan iklim, dikarenakan banyaknya izin usaha pertambangan yang beroperasi di wilayah Samarinda. Gugatan tersebut diputus oleh majelis hakim dengan mengabulkan sebagian gugatan warga Samarinda, yaitu menyatakan para tergugat lalai dalam melaksanakan kewajibannya untuk menciptakan lingkungan hidup yang baik dan sehat, yang mengakibatkan kerugian kepentingan umum bagi warga negara, khususnya warga kota Samarinda, menghukum para tergugat untuk mengatur kembali suatu kebijakan umum mengenai pertambangan batubara yang meliputi: evaluasi terhadap seluruh izin pertambangan batubara yang telah dikeluarkan, mengawasi pelaku usaha untuk merealisasikan reklamasi dan pasca tambang, perbaikan fungsi lingkungan hidup, melakukan upaya strategis dalam perlindungan kawasan pertanian dan perikanan masyarakat dari pencemaran sebagai akibat kegiatan pertambangan batubara. Selain itu, dalam pertimbangannya majelis hakim juga menyimpulkan bahwa perubahan iklim telah terjadi di seluruh dunia tidak terkecuali di Samarinda, yang ditandai dengan perubahan intensitas curah hujan, sehingga menyebabkan banjir di wilayah Samarinda serta menurunnya kualitas hidup warga karena tempat tinggal yang berdebu, panas dan sulit mendapatkan air bersih akibat aktivitas tambang. ${ }^{4}$

Rekonstruksi dalam konteks pembentukan peraturan perundang-undangan di bidang lingkungan hidup dan sumber daya alam, penaatan hukum lingkungan terletak pada instrumen perizinan lingkungan hidup yang utama, yakni tata ruang, Kajian Lingkungan Hidup Strategis (KLHS), dan Amdal sejatinya perlu mendapatkan partisipasi masyarakat dalam proses penyusunan kebijakan dan dokumen lingkungan hidup. Dengan partisipasi, diharapkan pelaku usaha atau masyarakat mampu meminimalisasi terjadinya pencemaran dan atau kerusakan lingkungan hidup dalam artian ketaatan terhadap instrumen perizinan lingkungan hidup. Filosofi dibalik norma instrumen perizinan lingkungan adalah dalam rangka menghadirkan hukum sebagai sarana pembaharuan masyarakat. Bahkan, teori hukum pembangunan yang digagas oleh Mochtar Kusumaatmadja memiliki

49 Untuk selebihnya lihat: Salinan Putusan Pengadilan Negeri Kota Samarinda Nomor 55/ Pdt.G/2013/PN Smda, perkara antara Komari, dkk (penggugat) melawan Walikota Samarinda, dkk (tergugat), 23 Juli 2014, hlm. 134. 
kesamaan dengan pemikiran Satjipto Rahardjo tentang hukum dan perubahan sosial. $^{50}$ Dalam tataran praksis operasional, pascareformasi dari instrumen perizinan lingkungan hidup memberikan nuansa baru kesadaran hukum bagi pelaku usaha untuk taat terhadap hukum perizinan. Proses penerbitan instrumen perizinan tersebut diharuskan melibatkan peran serta masyarakat berkaitan dengan dampak lingkungan yang timbul di kemudian hari, termasuk manfaat dan keseimbangan lingkungan. Namun, kelemahannya adalah pengendalian sebagai bagian dari pengawasan dari pemerintah daerah terhadap pelaku usaha yang melanggar ketentuan perundang-undangan dan tidak tegasnya dalam memberikan sanksi administrasi. Fungsi hukum sebagai sarana pembaharuan masyarakat pascareformasi dalam perspektif perundang-undangan lingkungan hidup dan sumber daya alam perlu direkonstruksi yang senantiasa berorientasi kepada kesejahteraan masyarakat yang ramah lingkungan, atau ekonomi berkelanjutan. Negara wajib memenuhi hak-hak ekonomi, sosial, budaya warga masyarakat sekitar yang tinggal di wilayah-wilayah sumber daya alam strategis, karena hak-hak tersebut sebagai bagian dari HAM dalam kebijakan lingkungan hidup dan sumber daya alam. Hubungan antara masyarakat dengan lingkungan adalah masyarakat yang merupakan sekumpulan dari anggota-anggota individu memiliki ketergantungan dengan lingkungan sebagai kehidupannya. Lingkungan sangatlah kompleks, merupakan kombinasi antara kondisi fisik yang mencakup keadaan sumber daya alam seperti tanah, air, energi surya, mineral, serta flora dan fauna yang tumbuh di atas tanah maupun di dalam lautan, dengan kelembagaan yang meliputi ciptaan manusia seperti keputusan bagaimana menggunakan lingkungan fisik tersebut. Lingkungan juga dapat diartikan menjadi segala sesuatu yang ada di sekitar manusia dan mempengaruhi perkembangan kehidupan manusia yang terdiri dari komponen abiotik dan biotik. Dalam tataran praksis

50 Satjipto Rahardjo mengidentifikasi apabila berbicara mengenai hukum dan perubahan sosial, maka relevansi masalah yang dikajinya itu ditentukan oleh dua hal, yaitu: (a) Berhubungan dengan fungsi hukum sebagai lembaga atau mekanisme untuk menertibkan masyarakat; dan (b) Berhubungan dengan masalaha perubahan sosial yang nampaknya merupakan suatu proses yang menjadi ciri masyarakat di dunia pada abad sekarang ini. Maka pembicaraan mengenai hukum dan perubahan sosial akan berkisar pada pengkajian tentang bagaimana hukum yang bertugas untuk menertibkan masyarakat dapat bersaing dengan perubahan sosial itu. Beberapa variabel yang mendorong timbulnya perubahan sosial diantaranya adalah: a. variabel fisik, biologi, dan demografi; b. variabel teknologi; dan c. variabel ideologi. Lihat: Satjipto Rahardjo, Pemanfaatan Ilmu-Ilmu Sosial Bagi Pengembangan Ilmu Hukum, Cet. 2, (Yogyakarta: Genta Publishing, 2010), hlm. 122. 
operasional, hukum pembangunan akan berjalan dengan baik apabila diikuti dengan kesadaran hukum masyarakat baik pemerintah, pelaku usaha, maupun masyarakat sekitar dalam konteks kesadaran melestarikan lingkungan. Hukum sebagai sarana pembaruan masyarakat bisa dicapai melalui instrumen peraturan, perizinan, dan kesadaran hukum masyarakat, atau terdapat timbal balik yang baik dengan masyarakat, dalam hal ini di bidang lingkungan hidup.

Hukum yang tidak mempunyai dimensi operasional, tidak mungkin berperanan untuk mengatur perilaku dan mengendalikan hubungan antar manusia dalam kesehariannya. Edmund Husserl seorang perintis fenomenologi, lebenswelt mengatakan bahwa dunia kehidupan itu hanya ada dalam pengalaman keseharian, atau seperti yang dikemukakan oleh Berger dan Luckmann bahwa hidup manusia yang merupakan konstruksi sosial dari kenyataan itu terjadi dalam kehidupan sehari-hari. Hal tersebut menjadikan alasan mengapa semua perumus undang-undang atau peraturan seharusnya selalu berusaha untuk menyusun ketentuan yang memuat rumusan dari suatu norma hukum dengan sejelas dan selogis mungkin, sehingga sejauh mungkin menutup kemungkinan, bahwa norma tersebut dibaca dan dipahami secara berlainan oleh para subjek hukum yang berbeda. ${ }^{51}$ Dalam konteks demikian, para pembuat undang-undang sudah seharusnya mengakomodasi apa yang menjadi kebutuhan masyarakat sebagai bahan masukan dalam proses pembuatan peraturan dan kebijakan yang konkrit, dengan demikian kemanfaatan akan tercapai karena bersumber dari kehendak masyarakat. Sementara pendapat Mochtar Kusumaatmadja sebagaimana yang dikutip oleh Suparnyo menyatakan bahwa hukum merupakan salah satu dari kaidah sosial (disamping kaidah moral, agama, kaidah susila, kesopanan, adat kebiasaan, dan lain-lain) yang merupakan cerminan dari nilai-nilai yang berlaku dalam masyarakat, sehingga hukum yang baik adalah hukum yang hidup (living

51 Budiono Kusumohamidjojo, op.cit., hlm. 238. 
law). ${ }^{52}$ Untuk merekonstruksi teori hukum pembangunan dalam kebijakan (legal policy) pembentukan hukum di bidang lingkungan dan sumber daya alam, haruslah memiliki optik dan pendekatan secara holistik komprehensif dan interdisipliner. Kerusakan lingkungan dan pencemaran pasca reformasi yang dikemas dalam bentuk regulasi dan kebijakan (keputusan pejabat tata usaha negara) menunjukkan proses pembentukannya tidak melibatkan peran serta masyarakat dan menjauhkan dari spirit hukum sebagai sarana pembaharuan masyarakat.

Hukum tidak selamanya menjalankan fungsinya dengan baik apabila dalam penerapannya menimbulkan kekakuan, penuh dengan lobi dan pemilik modal yang besar. Hal tersebut merupakan konsekuesi logis dari hukum yang disetir untuk kepentingan politik dan ekonomi oleh kebijakan penyelenggara negara, khususnya baik eksekutif dan legislatif. Agar penyusunan hukum dapat berjalan dengan baik, steril dan responsif, maka perlu adanya diskursus-diskursus dari masyarakat sipil yang berjalan secara komunikatif untuk mencapai suatu konsensus bersama tanpa adanya pertikaian. ${ }^{53}$

Untuk mengakhiri proses penyusunan undang-undang yang sarat kepentingan, menjauhkan hukum sebagai sarana pembaharuan masyarakat dan menjerat masyarakat ke ranah proses hukum, maka filosofi yang terkandung dalam cita hukum (rechtsidee) Pancasila sebenarnya diwujudkan dalam model-model partisipasi dan aspirasi masyarakat, membuka ruang komunikasi dan mendorong

52 Suparnyo, dalam Pembentukan dan Penegakan Hukum Progresif, Dekonstruksi dan Gerakan Pemikiran Hukum Progresif, Cet. I, (Yogyakarta: Diterbitkan atas kerjasama Thafa Media dengan Konsorsium Hukum Progresif Universitas Diponegoro Semarang, 2013), hlm. 155-156. Menurut Bruggink sebagaimana dialihbahasakan oleh Arief Sidharta mendefinisikan kaidah hukum adalah isi aturan hukum, dan bahwa aturan hukum itu dapat tertulis maupun tidak tertulis. pertanyaan apakah suatu aturan hukum tertulis atau tidak tertulis adalah tidak selalu dapat dijawab secara sederhana. Jika sebuah aturan hukum dirumuskan dalam sebuah undang-undang, maka orang dengan kepastian dapat mengatakan bahwa ia ditetapkan oleh pengemban kewenangan hukum dan karena itu termasuk dalam hukum positif. Namun memang ada aturan hukum yang oleh pembentuk undang-undang diandaikan pada waktu pembentukan aturan perundang-undangan, tanpa mereka dirumuskan sebagai demikian oleh pembentuk undang-undang. Dengan itu, aturan tersebut memang menjadi bagian dari hukum sebagai sistem konseptual, tetapi aturan itu tetap merupakan hukum tidak tertulis dan dengan demikian tidak termasuk dalam hukum positif. Arief Sidharta, op.cit., hlm. 91-92.

53 Wahyu Nugroho, “Menyusun Undang-Undang yang Responsif dan Partisipatif Berdasarkan Cita Hukum Pancasila", dalam Jurnal Legislasi Indonesia, Vol. 10, No. 3 September, (Jakarta: Direktorat Jenderal Peraturan Perundang-Undangan Kementerian Hukum dan Hak Asasi Manusia RI, 2013), hlm. 215. 
untuk mampu melihat fakta sosial sehingga keputusan hukum yang dibuat pembentuk undang-undang mencerminkan keadilan sosial dan memberikan manfaat bagi rakyatnya. Konsep yang digunakan Mochtar Kusumaatmadja dengan konsep Satjipto Rahardjo memiliki kesamaan dalam konteks fungsi hukum sebagai sarana perubahan sosial dan atau pembaharuan masyarakat. Satjipto Rahardjo selalu mengingatkan kepada kita semua, khususnya penyelenggara negara dan yang duduk di parlemen bahwa hukum dibuat untuk menyejahterakan rakyat, bukan malah menyengsarakan rakyatnya yang terlihat seperti di beberapa undangundang yang sering diuji materiil di Mahkamah Konstitusi (seperti UU Agraria, UU Kehutanan, UU Sumber Daya Air, UU Pengelolaan Wilayah Pesisir dan Pulaupulau Kecil, UU Pertambangan, Mineral dan Batubara dan UU Perkebunan).

\section{Simpulan}

Berdasarkan uraian pembahasan tersebut di atas, maka penulis dapat memberikan simpulan sebagai berikut:

Pertama, teori hukum pembangunan di sektor pengelolaan lingkungan hidup dalam perkembangan awal tidak berjalan dengan baik dikarenakan kuatnya kepentingan penguasa. Hukum itu pada akhirnya merupakan alat perebutan kekuasaan dalam masyarakat, yakni dominasi kekuasaan/politik dalam undangundang lingkungan hidup dengan semangat perubahan sosial dan pembaharuan masyarakat. selain hal tersebut, ditemukan terjadi ego sektoral diantara kementerian atau lembaga yang mestinya secara koordinatif menangani dan menyelesaikan permasalahan pencemaran atau kerusakan lingkungan, termasuk tidak ada sanksi yang tegas bagi pelaku kerusakan lingkungan. Perbedaan dari teori hukum pembangunan sebelumnya di bidang kebijakan lingkungan hidup, yakni pengembangan teori hukum pembangunan pascareformasi terkait kebijakan pengelolaan lingkungan hidup adalah ditunjukkan dengan transparansi dan peran masyarakat dalam proses pembuatan kebijakan melalui Undang-Undang Nomor 32 tahun 2009 tentang Perlindungan dan Pengelolaan Lingkungan Hidup, termasuk proses pembuatan instrumen perizinan lingkungan dan pengawasan. Selain itu, teori hukum pembangunan pasca reformasi akan memiliki daya laku yang efektif disaat masyarakat terlibat dan ikut serta dalam proses penyusunan 
dokumen lingkungan dan aktif menyuarakan hak-hak atas lingkungannya.

Kedua, rekonstruksi teori hukum pembangunan dalam kebijakan pembentukan hukum di bidang lingkungan hidup dan sumber daya alam pascareformasi, senantiasa diarahkan kepada daya dukung masyarakat (legal culture), kesejahteraan sosial, dan lingkungan hidup. Dalam konteks kebijakan pembentukan hukum lingkungan, partisipasi masyarakat menjadi hal yang utama dan diharapkan pelaku usaha, termasuk masyarakat mampu meminimalisasi terjadinya pencemaran dan atau kerusakan lingkungan hidup dalam artian ketaatan terhadap instrumen perizinan lingkungan hidup. Filosofi dibalik daya dukung masyakarat (legal culture) adalah dalam rangka menghadirkan hukum sebagai sarana pembaharuan masyarakat. Dalam merekonstruksi teori hukum pembangunan, pembuat kebijakan (legal policy) pembentukan hukum ranah legislatif di bidang lingkungan dan sumber daya alam, haruslah memiliki optik dan pendekatan secara holistik komprehensif dan interdisipliner. 


\section{Daftar Pustaka}

Amiq, Bachrul. 2013. Penerapan Sanksi Administrasi dalam Hukum Lingkungan. Cet. I, Yogyakarta: Laksbang Mediatama.

Dimyati, Khudzaifah. 2004. Teorisasi Hukum Studi tentang Perkembangan Pemikiran Hukum di Indonesia 1945-1990. Cet. I, Surakarta: Muhammadiyah University Press.

Friedmann, W. 1993. Teori dan Filasafat Hukum; Susunan I, (Legal Theory), terjemahan: Mohamad Arifin, Cetakan Kedua, Jakarta: PT. Raja Grafindo Perkasa.

Fuady, Munir. 2013. Teori-Teori Besar Dalam Hukum (Grand Theory). Cet. 2, Jakarta: Kencana Prenadamedia Group.

Galanter, Marc. 1988. "Hukum Hindu dan Perkembangan Sistem Hukum India Modern", dalam A.A.G. Peters dan Koesriani-Siswosoebroto (ed). Hukum dan Perkembangan Sosial. Buku Teks Sosiologi Hukum, Buku II, Jakarta: Pustaka Sinar Harapan.

Hart, H.L.A.. 1972. The Concept of Law. London: Oxford University Press.

Helmi. 2012. Hukum Perizinan Lingkungan Hidup. Cet. I, Jakarta: Sinar Grafika.

Huijbers, Theo. 1991. Filsafat Hukum. Yogyakarta: Kanisius.

Kelsen, Hans. 1945. General Theory of Law and State. New York: Russell \& Russell. 2006. Essays in Legal and Moral Philosophy, Hukum dan Logika. Alih bahasa: B. Arief Sidharta, Cet. 2, PT Alumni, Bandung.

Kusumaatmadja, Mochtar. 2002. Konsep-Konsep Hukum dalam Pembangunan. Cet. I, Bandung: PT Alumni.

Kusumohamidjojo, Budiono. 2016. Cet. I, Teori Hukum, Dilema antara Hukum dan Kekuasaan. Bandung: Penerbit Yrama Widya.

Laudjeng, Hedar dan Simarmata, Rikardo. 2000. Pendekatan Madhab Hukum NonPositivistik dalam Bidang Hukum Sumber Daya Alam dalam Wacana. Edisi 6 tahun II. Jakarta: HuMa. 
Manan, Bagir. 1995. Pertumbuhan dan Perkembangan Konstitusi Suatu Negara. Bandung: Mandar Maju.

MD., Moh. Mahfud. 1999. Pergulatan Politik dan hukum di Indonesia. Yogyakarta: Gama Media.

Mertokusumo, Sudikno. 1996. Penemuan Hukum Sebuah Pengantar. Yogyakarta: Liberty.

Nonet, Philippe and Selznick, Philip. 2001. terj., Hukum dan Masyarakat Dalam Transisi Menuju Hukum yang responsif. Jakarta: Media Nusantara.

Rahardjo, Satjipto. 2009. Lapisan-Lapisan Dalam Studi Hukum. Cet. I, Malang: Bayumedia Publishing. 2010. Pemanfaatan Ilmu-Ilmu Sosial Bagi Pengembangan Ilmu Hukum. Cet. 2, Yogyakarta: Genta Publishing.

Rasjidi, Lili dan Putra, I.B. Wyasa. 1993. Hukum Sebagai Suatu Sistem. Bandung: Remaja Rosda Karya.

Sidharta, Arief. 1999. Refleksi Tentang Hukum. Alih Bahasa dari Bruggink dalam buku "Rechtsreflecties", Cet. 2, PT Citra Aditya, Bandung.

Sigler, Jay A. and Beede, Benyamin R. 1978. The Legal Sources of Public Policy. Toronto: Lexington Books.

Soemanto, RB. 2006. Hukum dan Sosiologi Hukum, Lintasan Pemikiran, Teori dan Masalah. Surakarta: Sebelas Maret University Press.

Suparnyo, 2013. 'Pembentukan dan Penegakan Hukum Progresif', Dekonstruksi dan Gerakan Pemikiran Hukum Progresif. Cet. I, Yogyakarta: Diterbitkan atas kerjasama Thafa Media dengan Konsorsium Hukum Progresif Universitas Diponegoro Semarang.

Unger, Roberto Mangabeira. 1976. Law and Modern Society, Toward a Criticism of Social Theory. New York: The Free Press.

. Gerakan Hukum Kritis, (Critical Legal Studies). 1999. Diterjemahkan oleh Ifdhal Kasim, Jakarta: ELSAM.

Utomo, Laksanto. 2012. “Penerapan Hukum Progresif dalam Penemuan Hukum 
